\title{
In vitro antiplasmodial and cytotoxic properties of some medicinal plants from western Burkina Faso
}

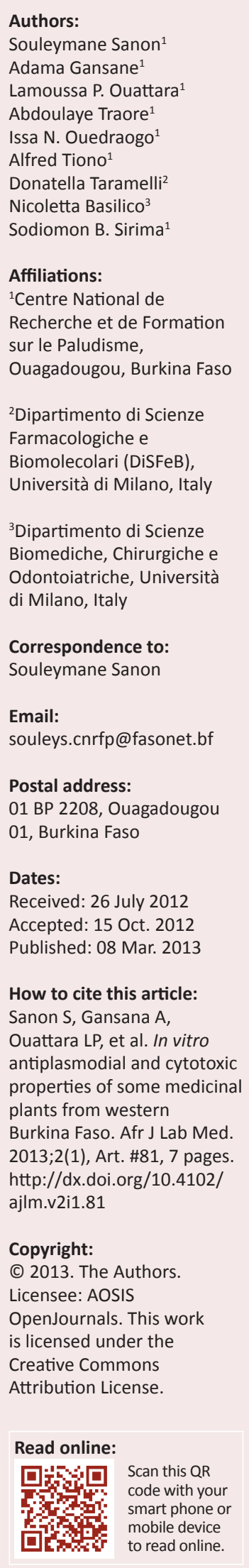

Background: Resistance of malaria parasites to existing drugs complicates treatment, but an antimalarial vaccine that could protect against this disease is not yet available. It is therefore necessary to find new effective and affordable medicines. Medicinal plants could be a potential source of antimalarial agents. Some medicinal plants from Burkina Faso were evaluated for their antiplasmodial and cytotoxic properties in vitro.

Methods: Crude dichloromethane, methanol, water-methanol, aqueous and alkaloids extracts were prepared for 12 parts of 10 plants. Chloroquine-resistant malaria strain K1 was used for the in vitro sensibility assay. The Plasmodium lactacte dehydrogenase technique was used to determine the $50 \%$ inhibitory concentration of parasites activity $\left(\mathrm{IC}_{50}\right)$. The cytotoxic effects were determined with HepG2 cells, using the tetrazolium-based colorimetric technique, and the selectivity index (SI) was calculated.

Results: Sixty crude extracts were prepared. Seven extracts from Terminalia avicenoides showed $\mathrm{IC}_{50}<5 \mu \mathrm{g} / \mathrm{mL}$. The $\mathrm{IC}_{50}$ of dichloromethane, methanol, aqueous and alkaloids extracts ranged between $1.6 \mu \mathrm{g} / \mathrm{mL}$ and $4.5 \mu \mathrm{g} / \mathrm{mL}$. Three crude extracts from Combretum collinum and three from Ficus capraefolia had an $\mathrm{IC}_{50}$ ranging between $0.2 \mu \mathrm{g} / \mathrm{mL}$ and $2.5 \mu \mathrm{g} / \mathrm{mL}$. Crude extracts from these three plants had no cytotoxic effect, with SI $>1$. The other plants have mostly moderate or no antimalarial effects. Some extracts from Cordia myxa, Ficus capraefolia and Opilia celtidifolia showed cytotoxicity, with an SI ranging between 0.4 and 0.9 .

Conclusion: Our study showed a good antiplasmodial in vitro activity of Terminalia avicenoides, Combretum collinum and Ficus capraefolia. These three plants may contain antiplasmodial molecules that could be isolated by bio-guided phytochemical studies.

\section{Introduction}

Malaria remains a serious worldwide health problem due to the emergence and spread of parasite resistance to well-established antimalarial drugs and mosquito vectors resistant to insecticides. ${ }^{1}$ In sub-Saharan African populations, malaria is one of the diseases causing most morbidity and mortality. It is estimated that each year malaria causes nearly 800000 deaths, ,,3 mostly of African children aged below 5 years. In Burkina Faso, malaria is the leading cause of hospitalisation, with 2 million cases per year, and it remains also the principal cause of death in local health centers, with a rate of $50.7 \%$ in $2009 .{ }^{4}$ Although continued attempts to develop a vaccine for malaria are ongoing, distribution of mosquito nets, household spraying, and prophylaxis remain the primary prevention methods and antimalarial drugs remain the only treatment option. ${ }^{5}$ In order to decrease the risk of chemo-resistance to most of the antimalarial drugs, the World Health Organization (WHO) has recommended artemisinin-based combination therapies (ACTs) for the management of uncomplicated P. falciparum malaria cases. Unfortunately, ACT treatment failures have been reported in some countries. ${ }^{6,7,8}$ In addition, these drugs are expensive, limiting their use in a population with average annual income around $\$ 100$. Thus the use of traditional and less expensive preparations is common. ${ }^{10}$ Historically, many drugs effective against parasitic diseases stem from traditional medicine, such as quinine and artemisinin. . $^{11,12,13}$ Today, $30 \%$ of drugs on the pharmaceutical market come from nature ${ }^{14}$ and medicinal plants constitute a popular source of potential antimalarial agents. In the in western area of Burkina Faso, ten medicinal plants are widely used by traditional healers, ${ }^{15}$ although little scientific data exist on their effectiveness in treating malaria. The aim of this study is to determine which of these plants show promising antimalarial effects as well as low toxicity in vitro, paving the way for potential pharmaceutical development.

\section{Material and methods}

This study was approved by the national ethical committee to be conducted with the traditional healers on the study site. 


\section{Study site and plants}

The study was conducted in the province of Comoe, where malaria transmission is continuous and which covers $15871 \mathrm{~km}^{2}$ with 277384 inhabitants. With an average annual rainfall of $900 \mathrm{~mm}$, this area is one of the wetter regions of the country, and has a large plant biodiversity. The herbal pharmacopoeia has expanded rapidly in this province, and traditional healers collaborate with researchers in the field of herbal medicine. Twelve samples consisting of leaves and bark from ten plants (Terminalia avicenoides, Combretum collinum, Ficus capraefolia, Anthocleista nobilis, Celtis integrifolia, Cordia myxa, Lophira lanceolata, Oppilia celtidifolia, Securinega virosa and Tapinanthus dodoneifolius) were identified. The scientific identification and the herbarium were made by botanical taxonomists from the Centre National de Recherche Scientifique et Technologique (CNRST) of Burkina Faso. The specimen voucher number from this herbarium was deposited in Centre National de Recherche et de Formation sur le Paludisme (CNRFP). These parts of plants were used by traditional healers to treat malaria-like symptoms. Samples were harvested during the rainy season, washed, dried and pulverised for phytochemical extractions.

\section{Crude extracts preparation}

Extraction based on maceration, decoction and preferential depletion methods were used to obtain five types of extract for each of the 12 plant parts. We obtained three organic extracts, one aqueous with water, and one crude alkaloid. Crude organic extracts were prepared by maceration for 16 hours successively with dichloromethane $\left(\mathrm{CH}_{2} \mathrm{Cl}_{2}\right)$, methanol $\left(\mathrm{CH}_{3} \mathrm{OH}\right)$ and water-methanol $\left(\mathrm{CH}_{3} \mathrm{OH} / \mathrm{H}_{2} \mathrm{O}\right)$ solvents. Plant powder (20 g) was used for these organic extraction methods with $500 \mathrm{~mL}$ of each solvent. $\mathrm{CH}_{2} \mathrm{Cl}_{2}$ extract was air dried at room temperature. $\mathrm{CH}_{3} \mathrm{OH}$ and $\mathrm{CH}_{3} \mathrm{OH} / \mathrm{H}_{2} \mathrm{O}$ extracts were freeze-dried with lyophilisator (Brand) after total evaporation of solvents. Aqueous extracts were prepared by boiling $10 \mathrm{~g}$ of plant powder in $500 \mathrm{~mL}$ of purified water for 30 minutes. After cooling, solutions were filtered on cotton wool and freeze-dried. Crude alkaloid extracts were obtained by alkalinisation with $\mathrm{NH}_{4} \mathrm{OH}$ of the plant powder and extraction with $\mathrm{CH}_{2} \mathrm{Cl}_{2}$ for 24 hours. Plant powder $(20 \mathrm{~g})$ was used by applying the classical alkaloids extraction method. ${ }^{16}$ After 16 hours of maceration with ammoniac and $\mathrm{CH}_{2} \mathrm{Cl}_{2}$, a percolation was made with $\mathrm{CH}_{2} \mathrm{Cl}_{2}$ solvent. Then $500 \mathrm{~mL}$ of dichloromethane layer was concentrated under vacuum and then extracted with a $2 \%$ solution of $\mathrm{H}_{2} \mathrm{SO}_{4}$. The aqueous acid solution was alkalinised again with $\mathrm{NH}_{4} \mathrm{OH}$ and extracted with $\mathrm{CH}_{2} \mathrm{Cl}_{2}$, and a crude alkaloids extract was obtained by concentration.

Each of the 60 extracts was dissolved in appropriate solvent of dimethyl sulfoxide (DMSO) and purified water (DMSO/water) to give a homogeneous solution at an initial concentration of $1 \mathrm{mg} / \mathrm{mL}$. Samples were then serially diluted with complete culture media (RPMI 1640 with albumax) to achieve the required concentration with DMSO concentration $<0.5 \%$.

\section{In vitro antiplasmodial assays}

\section{Plasmodium falciparum culture}

Sixty extracts were tested for their effectiveness in preventing growth of the most common chloroquine-resistant strain of malaria found in Burkina Faso, Plasmodium falciparum $\mathrm{K} 1$. The malaria strains were provided by the London School of Tropical Medicine and Hygiene (England) and were grown under standard conditions as previously described. ${ }^{17}$ They were maintained in continuous culture at the CNRFP, in a sterile atmosphere under a laminar flow hood in $200 \mu \mathrm{L}$ blood group O+ using RPMI 1640 (MegaCell, Sigma Aldrich, USA) medium (5 mL) supplemented with 2-hydroxyethlpiperazine-N-2ethanesulfonic acid (HEPES acid) (25 mM; Gibco-BRL, Paisley, Scotland), $\mathrm{NaHCO}_{3}$ (25 mM), 1\% Albumax and washed erythrocytes to yield a final haematocrit of $4 \%$. Parasitaemia was maintained between $1 \%$ and $6 \%$ by dilution with non-infected $\mathrm{O}+$ erythrocytes. Blood was obtained from subjects who had not received antimalarial treatment during the previous two weeks and had an AA electrophoresis (no sickle cell trait). The $75 \mathrm{~cm}^{3}$ culture flasks were incubated for 24 hours at $37{ }^{\circ} \mathrm{C}$ in a $\mathrm{CO}_{2}$ incubator (HeraCell 150, Forma Scientific), with $2 \% \mathrm{O}_{2}, 5 \% \mathrm{CO}_{2}, 93 \% \mathrm{~N}_{2}$ and $90 \%$ humidity. Every 24 hours, supplemented media was renewed and parasitemia was checked by blood smear with optical microscope.

\section{Evaluation of antiplasmodial effect of extracts}

Antimalarial effects were quantified with respect to inhibition of parasite growth, as measured by the production of Plasmodium lactate dehydrogenase $(\mathrm{pLDH})$. Testing was performed in three steps in duplicate in 96-well flat bottom plates (TPP, Switzerland).

Malaria parasites were cultured with seven different concentrations of each extract and parasite growth was assessed by the production of pLDH. Each extract was applied in a series of seven duplicate dilutions (final concentrations ranging from $0.78 \mu \mathrm{g} / \mathrm{mL}$ to $50 \mu \mathrm{g} / \mathrm{mL}$ ) on two rows. $100 \mu \mathrm{L}$ of asynchronous parasitised erythrocytes at a hematocrit of $2 \%$ with parasitemia between $1.5 \%$ and $2 \%$ were prepared in $100 \mu \mathrm{L}$ of each extract. The plates were then placed at $37{ }^{\circ} \mathrm{C}$ in a modular incubator chamber with a humidified atmosphere of the same gas mixture as above for 72 hours. Dihydroartemisinin was used to validate the malaria test and chloroquine diphosphate salt (Sigma Aldrich) was used to validate the real chloroquine resistance of malaria strain $\mathrm{K} 1$. Infected and uninfected erythrocytes $\mathrm{O}+$ were used as positive and negative controls, respectively. Parasite growth was determined by measuring the content of parasite lactate dehydrogenase $^{18}$ using Malstat, NTB/PES reagents. The microplates were read with a spectrophotometer (Biotek EL x 808) at a wavelength of $650 \mathrm{~nm}$. Absorbance data were entered into Microsoft Excel to calculate the percent inhibition relative to positive control from the mean of raw data for each concentration. Table Curve version 5.0 software was used to plot inhibition curves and calculate the inhibition concentration of drug that reduced the pLDH activity by 
$50 \%\left(\mathrm{IC}_{50}\right)$. The results were categorised following Deharo's et al classification: ${ }^{19}$ good antimalarial effect $\mathrm{IC}_{50}<5 \mu \mathrm{g} / \mathrm{mL}$, moderate antimalarial effect $5 \mu \mathrm{g} / \mathrm{mL} \leq \mathrm{IC}_{50}<10 \mu \mathrm{g} / \mathrm{mL}$ and inactive extract $\mathrm{IC}_{50} \geq 10 \mu \mathrm{g} / \mathrm{mL}$.

\section{In vitro cytotoxicity assay of extracts on human cells}

Human hepatoma cells ATCC \# HB-8065 (HepG2) were obtained from the American Type Culture Collection (ATCC, Manassas, USA). The cells were grown in RPMI1640 (MegaCell, Sigma Aldrich, USA) supplemented with $10 \%$ Fetal Bovine Serum (v/v), 1\% mix (v/v) of $200 \mathrm{mM}$ L-glutamine, $10000 \mathrm{IU} / \mathrm{mL}$ penicillin and $10 \mathrm{mg} / \mathrm{mL}$ streptomycine, (GibcoBRL) within a humidified atmosphere of $6 \% \mathrm{CO}_{2}$ and $94 \%$ de $\mathrm{N}_{2}$ at $37{ }^{\circ} \mathrm{C}$ over 5 days. Cultures were maintained by sub-culturing flasks every 4 days at $5 \times 10^{4}$ cells $/ 25 \mathrm{~cm}^{2}$ flask by trypsination. The cytotoxicity of the extracts was assessed using a tetrazolium salt MTT (3-[4.5-dimethylthiazol-2-yl]-2.5-diphenyltetrazolium bromide) (Sigma) colorimetric method, based on reagent cleavage by mitochondrial dehydrogenase in viable cells. ${ }^{20}$ Growing cells were placed at a density of $5 \times 10^{4}$ cells per well in microplates in $100 \mu \mathrm{L}$ of culture medium. The microplates were incubated in a humidified atmosphere of $6 \% \mathrm{CO}_{2}$ and $94 \% \mathrm{~N}_{2}$ at $37{ }^{\circ} \mathrm{C}$ for 24 hours. For each extract, seven duplicate dilutions were prepared with concentrations ranging from $0.78 \mu \mathrm{g} / \mathrm{mL}$ to $50 \mu \mathrm{g} / \mathrm{mL}$ in DMSO and then in medium culture. For each test, we used a growth (cells plus medium only), positive (with doxorubicin) and a negative control (with DMSO) respectively. Cytotoxicity was scored as the percentage reduction in absorbance at $570 \mathrm{~nm}$ versus that of the untreated control culture. A selectivity index (SI), corresponding to the ratio between antimalarial and cytotoxic properties, was calculated according to the following formula: $\mathrm{SI}_{\text {extract }}=\mathrm{IC}_{50 \text { cytotoxic }} / \mathrm{IC}_{50 \text { malaria }}$. The extract was considered to have negligible cytotoxicity if $\mathrm{SI}>1 .{ }^{21}$

\section{Results}

\section{Antimalarial effects}

Among the 60 extracts tested, 21 were identified as having good antimalarial effects ( $\mathrm{IC}_{50}<5 \mu \mathrm{g} / \mathrm{mL}$ ), 14 with moderate effects $\left(5 \mu \mathrm{g} / \mathrm{mL} \leq \mathrm{IC}_{50}<10 \mu \mathrm{g} / \mathrm{mL}\right)$, and 25 as inactive ( $\mathrm{IC}_{50} \geq 10 \mu \mathrm{g} / \mathrm{mL}$ ) (Table 1 ). Terminalia avicenoides produced the most effective antimalarial extracts, with four coming from its leaves and three from its stem bark (Table 2). Three extracts from Combretum collinum and three from Ficus capraefolia also had good antimalarial effects (Table 2). Extracts from the seven other plants had mostly moderate to little effect.

\section{Toxicity}

The extracts with antiplasmodial effects from Terminalia avicenoides, Combretum collinum and Ficus capraefolia, had low risk of cytotoxicity (SI > 1), with SI ranging from 4 to 140 (Table 1). Higher risk of cytotoxicity $(\mathrm{SI}<1)$ was found with five extracts from four plants: a water-methanol extract from
Celtis integrifolia (SI > 0.5), methanol and water-methanol extracts from Cordial myxa (SI $=0.9$ and SI $=0.5$, respectively), aqueous extract from Ficus capraefolia (SI $=0.4)$ and watermethanol extract from Opilia celtidifolia $(\mathrm{SI}=0.4)$.

\section{Discussion}

The best antimalarial effects were obtained with extracts of three plants, namely, Terminalia avicenoides, Combretum collinum and Ficus capraefolia. The four crude extracts from the leaves and three from the stem bark of Terminalia avicenoides showed good antimalarial effects against the CQ-resistant strain $\mathrm{K} 1$, with $\mathrm{IC}_{50}$ values ranging between $1.16 \mu \mathrm{g} / \mathrm{mL}$ to $4.53 \mu \mathrm{g} / \mathrm{mL}$. In Nigeria, a similar study showed that methanol extracts of leaves of Terminalia avicennoides had an $\mathrm{IC}_{50}=14.09 \mu \mathrm{g} / \mathrm{mL}$ with the $\mathrm{K} 1$ malaria strain..$^{22}$

Based on Deharo's efficiency criteria, results from Nigeria are different from our findings. These differences may be related to many parameters, including the local environment and the collection periods, which contribute to the variation of plant chemical components as shown in a previous study on seasonal effects on bioactive compounds. ${ }^{23}$ The biological results could be linked to the laboratory techniques used. In phytochemical studies, extraction methods are often different because the ability of extracting a solvent of chemical groups is related to its polarity. Concerning biological assessment, the results are often based on the sensitivity of techniques used. A previous study done in Australia pointed to the difference of sensitivity of the Flow cytometry assay, the Sybr Green plate reader assay, the Plasmodium falciparum lactate dehydrogenase assay and light microscopy used in in vitro antiplasmodial activity assessments. ${ }^{24}$

Despite the difference of $\mathrm{IC}_{50}$ values obtained, which could be related to laboratory sensitivity techniques and environmental conditions, the antiplasmodial properties of Terminalia avicenoides were promising. Our study confirms the pharmacological properties of this plant species shown by its antifungal activity against Candida albicans ${ }^{25}$ and parasitogical activity on Trypanosoma mali. ${ }^{26}$ Another study showed good antidiarrheal properties for an aqueous extract of the roots of Terminalia avicennoides. ${ }^{27}$ It is recommended that future studies should consider this plant as a potential source of antiplasmodial molecules. Our study appears to be the first to demonstrate the antimalarial effects of this plant.

With Combretum collinum, dichloromethane, water-methanol and alkaloid extracts of leaves had good antimalarial activity, with $\mathrm{IC}_{50}$ values ranging from $0.2 \mu \mathrm{g} / \mathrm{mL}$ to $2.14 \mu \mathrm{g} / \mathrm{mL}$. It appears that our findings are the first report of extracts exhibiting in vitro antiplasmodial activities. However, studies have shown the pharmacological property of some species of the same botanical family (Combretaceae). Acetone extracts from Combretum molle, which belongs to the same botanical family, have shown good antimalarial effects, with $\mathrm{IC}_{50}$ values from $2.2 \mu \mathrm{g} / \mathrm{mL}^{28}$ to $8.2 \mu \mathrm{g} / \mathrm{mL}^{28}$ and selective inhibition effect of HIV-1 replication. ${ }^{29}$ The plant also has antifungal, anti-inflammatory and antilarvicidal properties. ${ }^{30,31,32}$ According to these results, the antimalarial effect obtained with Combretum 
TABLE 1: In vitro antimalarial and cytotoxic effects of indigenous plant extracts.

\begin{tabular}{|c|c|c|c|c|c|c|c|c|}
\hline $\begin{array}{l}\text { Plant Species } \\
\text { (Botanical family) }\end{array}$ & Local name & $\begin{array}{l}\text { Administration } \\
\text { method }\end{array}$ & Plant part & Extract & $\begin{array}{l}\mathrm{IC}_{50}(\mathrm{~K} 1) \\
(\mu \mathrm{g} / \mathrm{mL})\end{array}$ & $\begin{array}{c}\text { Level of } \\
\text { antimalarial effect }^{\mathrm{a}}\end{array}$ & SI & $\begin{array}{c}\text { Level of } \\
\text { cytotoxic risk }^{b}\end{array}$ \\
\hline \multirow{10}{*}{$\begin{array}{l}\text { Terminalia avicennioides } \\
\text { (Combretaceae) }\end{array}$} & \multirow{10}{*}{$\begin{array}{l}\text { Kù’nhil- blïnngù (G), } \\
\text { Kokogo (K) }\end{array}$} & \multirow[t]{10}{*}{ Oral, Body bath } & \multirow[t]{5}{*}{ Leaves } & $\mathrm{CH}_{2} \mathrm{Cl}_{2}$ & 1.6 & Good & 32.0 & Low \\
\hline & & & & $\mathrm{CH}_{3} \mathrm{OH}$ & 1.9 & Good & 26.2 & Low \\
\hline & & & & $\mathrm{CH}_{3} \mathrm{OH} / \mathrm{H}_{2} \mathrm{O}$ & 5.4 & Moderate & 9.2 & Low \\
\hline & & & & $\mathrm{H}_{2} \mathrm{O}$ & 2.6 & Good & 19.4 & Low \\
\hline & & & & alkaloids & 1.2 & Good & 43.1 & Low \\
\hline & & & \multirow[t]{5}{*}{ Bark } & $\mathrm{CH}_{2} \mathrm{Cl}_{2}$ & 3.6 & Good & 13.7 & Low \\
\hline & & & & $\mathrm{CH}_{3} \mathrm{OH}$ & 4.5 & Good & 11.0 & Low \\
\hline & & & & $\mathrm{CH}_{3} \mathrm{OH} / \mathrm{H}_{2} \mathrm{O}$ & 7.4 & Moderate & 6.8 & Low \\
\hline & & & & $\mathrm{H}_{2} \mathrm{O}$ & 6.8 & Moderate & 7.3 & Low \\
\hline & & & & alkaloids & 2.9 & Good & 17.3 & Low \\
\hline \multirow{5}{*}{$\begin{array}{l}\text { Combretum collinum } \\
\text { (Combretaceae) }\end{array}$} & \multirow[t]{5}{*}{ Kagan-ga (M) } & \multirow[t]{5}{*}{ Oral, Body bath } & \multirow[t]{5}{*}{ Leaves } & $\mathrm{CH}_{2} \mathrm{Cl}_{2}$ & 0.2 & Good & 140.2 & Low \\
\hline & & & & $\mathrm{CH}_{3} \mathrm{OH}$ & 11.2 & Inactive & 3.2 & Low \\
\hline & & & & $\mathrm{CH}_{3} \mathrm{OH} / \mathrm{H}_{2} \mathrm{O}$ & 2.1 & Good & 21.1 & Low \\
\hline & & & & $\mathrm{H}_{2} \mathrm{O}$ & 38.4 & Inactive & 1.3 & Low \\
\hline & & & & alkaloids & 0.4 & Good & 113.6 & Low \\
\hline \multirow[t]{5}{*}{ Ficus capraefolia (Moraceae) } & \multirow[t]{5}{*}{ Ka funa sô (D) } & \multirow{5}{*}{$\begin{array}{l}\text { Oral, Body bath, } \\
\text { Steam bath }\end{array}$} & \multirow[t]{5}{*}{ Leaves } & $\mathrm{CH}_{2} \mathrm{Cl}_{2}$ & 1.8 & Good & 27.0 & Low \\
\hline & & & & $\mathrm{CH}_{3} \mathrm{OH}$ & 2.5 & Good & 4.9 & Low \\
\hline & & & & $\mathrm{CH}_{3} \mathrm{OH} / \mathrm{H}_{2} \mathrm{O}$ & 12.5 & Inactive & 2.0 & Low \\
\hline & & & & $\mathrm{H}_{2} \mathrm{O}$ & 13.1 & Inactive & 0.4 & High \\
\hline & & & & alkaloids & 0.9 & Good & 52.6 & Low \\
\hline \multirow{5}{*}{$\begin{array}{l}\text { Anthocleista nobilis } \\
\text { (Loganiaceae) }\end{array}$} & Falatô-dêbê (D), & Oral, Body bath, & Leaves & $\mathrm{CH}_{2} \mathrm{Cl}_{2}$ & 10.0 & Moderate & 5.0 & Low \\
\hline & & & & $\mathrm{CH}_{3} \mathrm{OH}$ & 30.2 & Inactive & 1.6 & Low \\
\hline & & & & $\mathrm{CH}_{3} \mathrm{OH} / \mathrm{H}_{2} \mathrm{O}$ & 20.7 & Inactive & 1.2 & Low \\
\hline & & & & $\mathrm{H}_{2} \mathrm{O}$ & 38.4 & Inactive & 1.3 & Low \\
\hline & & & & alkaloids & 1.8 & Good & 27.0 & Low \\
\hline Celtis integrifolia (Ulmaceae) & Kanga (M) & Oral, Body bath & Leaves & $\mathrm{CH}_{2} \mathrm{Cl}_{2}$ & 3.7 & Good & 13.4 & Low \\
\hline & & & & $\mathrm{CH}_{3} \mathrm{OH}$ & 46.8 & Inactive & 1.1 & Low \\
\hline & & & & $\mathrm{CH}_{3} \mathrm{OH} / \mathrm{H}_{2} \mathrm{O}$ & 47.5 & Inactive & 0.5 & High \\
\hline & & & & $\mathrm{H}_{2} \mathrm{O}$ & 20.6 & Inactive & 2.4 & Low \\
\hline & & & & alkaloids & 10.8 & Inactive & 4.6 & Low \\
\hline Cordia myxa (Boraginaceae) & Dàmàtéré (T) & Oral, Body bath, & Leaves & $\mathrm{CH}_{2} \mathrm{Cl}_{2}$ & 6.2 & Moderate & 8.0 & Low \\
\hline & & & & $\mathrm{CH}_{3} \mathrm{OH}$ & 21.6 & Inactive & 0.9 & High \\
\hline & & & & $\mathrm{CH}_{3} \mathrm{OH} / \mathrm{H}_{2} \mathrm{O}$ & 94.6 & Inactive & 0.5 & High \\
\hline & & & & $\mathrm{H}_{2} \mathrm{O}$ & 15.4 & Inactive & 3.2 & Low \\
\hline & & & & alkaloids & 4.2 & Good & 11.8 & Low \\
\hline Lophira lanceolata & Nô'ng-plà'ng (K) & Oral, Body bath & Leaves & $\mathrm{CH}_{2} \mathrm{Cl}_{2}$ & 4.7 & Good & 10.5 & Low \\
\hline & & & & $\mathrm{CH}_{3} \mathrm{OH}$ & 38.4 & Inactive & 1.3 & Low \\
\hline & & & & $\mathrm{CH}_{3} \mathrm{OH} / \mathrm{H}_{2} \mathrm{O}$ & 22.1 & Inactive & 2.3 & Low \\
\hline & & & & $\mathrm{H}_{2} \mathrm{O}$ & 12.5 & Inactive & 3.9 & Low \\
\hline & & & & alkaloids & 5.9 & Moderate & 8.5 & Low \\
\hline & & & Bark & $\mathrm{CH}_{2} \mathrm{Cl}_{2}$ & 5.5 & Moderate & 9.1 & Low \\
\hline & & & & $\mathrm{CH}_{3} \mathrm{OH}$ & 9.8 & Moderate & 9.5 & Low \\
\hline & & & & $\mathrm{CH}_{3} \mathrm{OH} / \mathrm{H}_{2} \mathrm{O}$ & 14.7 & Inactive & 1.7 & Low \\
\hline & & & & $\mathrm{H}_{2} \mathrm{O}$ & 4.7 & Good & 5.3 & Low \\
\hline & & & & alkaloids & 2.5 & Good & 19.8 & Low \\
\hline Opilia celtidifolia (Opiliaceae) & Ku'nhil-blingù (G) & Oral, Body bath & Leaves & $\mathrm{CH}_{2} \mathrm{Cl}_{2}$ & 2.8 & Good & 17.4 & Low \\
\hline & & & & $\mathrm{CH}_{3} \mathrm{OH}$ & 16.2 & Inactive & 3.1 & Low \\
\hline & & & & $\mathrm{CH}_{3} \mathrm{OH} / \mathrm{H}_{2} \mathrm{O}$ & 61.2 & Inactive & 0.4 & High \\
\hline & & & & $\mathrm{H}_{2} \mathrm{O}$ & 15.1 & Inactive & 3.3 & Low \\
\hline & & & & alkaloids & 6.9 & Moderate & 7.2 & Low \\
\hline Securinega virosa & Sï'ngnamâ (G) & Oral, Body bath & Leaves & $\mathrm{CH}_{2} \mathrm{Cl}_{2}$ & 7.1 & Moderate & 7.0 & Low \\
\hline & & & & $\mathrm{CH}_{3} \mathrm{OH}$ & 7.6 & Moderate & 2.7 & Low \\
\hline & & & & $\mathrm{CH}_{3} \mathrm{OH} / \mathrm{H}_{2} \mathrm{O}$ & 9.7 & Moderate & 1.8 & Low \\
\hline & & & & $\mathrm{H}_{2} \mathrm{O}$ & 14.5 & Inactive & 3.5 & Low \\
\hline & & & & alkaloids & 1.6 & Good & 31.8 & Low \\
\hline Tapinanthus dodoneifolius & Sï-làdon (D) & Oral, Body bath, & Leaves & $\mathrm{CH}_{2} \mathrm{Cl}_{2}$ & 6.5 & Moderate & 7.7 & Low \\
\hline & & & & $\mathrm{CH}_{3} \mathrm{OH}$ & 5.2 & Moderate & 7.4 & Low \\
\hline & & & & $\mathrm{CH}_{3} \mathrm{OH} / \mathrm{H}_{2} \mathrm{O}$ & 20.6 & Inactive & 1.2 & Low \\
\hline & & & & $\mathrm{H}_{2} \mathrm{O}$ & 43.7 & Inactive & 1.1 & Low \\
\hline & & & & alkaloids & 11.3 & Inactive & 4.4 & Low \\
\hline
\end{tabular}


TABLE 2: Promising crude extracts from medicinal plants according to antiplasmodial activity level and cytotoxicity.

\begin{tabular}{|c|c|c|c|c|}
\hline \multirow[t]{2}{*}{ Plant species } & \multicolumn{3}{|c|}{ Antiplasmodial activity level } & \multirow[t]{2}{*}{ Cytotoxicity (IS > 1) } \\
\hline & Good $\left(\mathrm{IC}_{50}<5 \mu \mathrm{g} / \mathrm{mL}\right)$ & Moderate $\left(5 \leq \mathrm{IC}_{50}<10 \mu \mathrm{g} / \mathrm{mL}\right)$ & Low $\left(\mathrm{IC}_{50} \geq 10 \mu \mathrm{g} / \mathrm{mL}\right)$ & \\
\hline Terminalia avicenoides & $\begin{array}{c}\text { Ext. DC (leaves, bark) } \\
\text { Ext. MT (leaves, bark) } \\
\text { Ext. AQ (leaves) } \\
\text { Ext. ACE (leaves, bark) }\end{array}$ & $\begin{array}{l}\text { Ext. HMT (leaves, bark) } \\
\text { Ext. AQ (bark) }\end{array}$ & No extracts & No extract $(7.3 \leq \mathrm{IS} \leq 43.1)$ \\
\hline Combretum collinum & $\begin{array}{l}\text { Ext. DC (leaves) } \\
\text { Ext. DMT (leaves) } \\
\text { Ext. ACE (leaves) }\end{array}$ & No extracts & $\begin{array}{l}\text { Ext. MT (leaves) } \\
\text { Ext. AQ (leaves) }\end{array}$ & No extract $(1.3 \leq \mathrm{IS} \leq 140.2)$ \\
\hline
\end{tabular}

Ext. DC, Dichloromethane extract; Ext. MT, Methanol extract; Ext. HMT, Hydro methanol extract, Ext. AQ, Aqueous extract; Ext. ACE, Crude alkaloids extract.

collinum can be explained by the presence of chemical groups specific to this botanical family.

Ficus capraefolia is the third plant which has good antimalarial effect, with dichloromethane, methanol and crude alkaloid extracts $\left(\mathrm{IC}_{50}<5 \mu \mathrm{g} / \mathrm{mL}\right.$ ranging between $0.95 \mu \mathrm{g} / \mathrm{mL}$ and $2.85 \mu \mathrm{g} / \mathrm{mL}$ ). Our study appears to be the first report to show the antimalarial activity of this plant. Other studies have shown pharmacological properties of other species of the same botanic family (Moraceae).

Thus, Ficus sycomorus (L) had a moderate antimalarial effect with $\mathrm{IC}_{50}<10 \mu \mathrm{g} / \mathrm{mL}^{16}$ and Ficus sur (Forssk) was inactive, with $\mathrm{IC}_{50}=27.4 \mu \mathrm{g} / \mathrm{mL}$ and $\mathrm{IC}_{50}>100 \mu \mathrm{g} / \mathrm{mL}$ using chloroquine resistant strains ENT 30 and VI/S respectively. ${ }^{33}$ In the other species of Moraceae, which is Ficus fistulosa Reinw, molecules such as the flavonoid artonin F, flavonoid 7-demethylartonol and flavonoid cycloartobiloxanthone have been isolated. ${ }^{34,35}$ The pharmacological effects that our study and others show could be attributed to this chemical group, but a bioguided phytochemical study would be necessary to verify whether it has the same antimalarial molecules as the ones found in our species.

Besides the three previous plant species, Anthocleista nobilis, Opilia celtidifolia, Lophira lanceolata, Securinega virosa and Tapinanthus dodoneifolius all showed moderate antimalarial activity. A literature search on the antimalarial activities of the aforementioned plants has shown no data. These pharmacological properties could be attributed to alkaloids which could be contained in this plant. ${ }^{36,37}$ Analgesic properties $^{38}$ and antibacterial activity ${ }^{39}$ of ethanol and methanol extracts have been shown in Cordia mixa.

In Kenya, aqueous and methanol extracts from leaves of Securinega virosa showed antimalarial activity using the CQresistant strain D6 with $\mathrm{IC}_{50}$ of $25.52 \mu \mathrm{g} / \mathrm{mL}$ and $2.28 \mu \mathrm{g} / \mathrm{mL}$ respectively. ${ }^{40}$ Our study confirms the antimalarial property shown by the Kenyan study, using another CQ-resistant strain K1. Otherwise, this antimalarial effect could be attributed to virosecurinine, an alkaloid isolated from its leaves. ${ }^{41}$ Our study appears to be the first report showing a moderate antimalarial effect for Lophira lanceolata but its antimicrobial activity against Candida albicans has been described previously in Cameroun. ${ }^{42}$ In Nigeria, a study showed that a methanol extract of the leaves of Tapinanthus dodoneifolius has very good antimicrobial properties. ${ }^{43}$
The promising antimalarial extracts from Terminalia avicenoides, Combretum collinum and Ficus capraefolia showed no cytotoxic effect, with a high selectivity index $>10$. This finding is in concordance with some cytotoxicity studies of extracts from African medicinal plants. ${ }^{44,45}$ Otherwise, among the extracts which have moderate and no antimalarial effects, the risk of cytotoxicity for human cells has been reported, as shown by water-methanol extracts from Celtis integrifolia (SI > 0.5), methanol and water-methanol extracts from Cordia myxa (respectively SI $=0.9$ and SI $=0.5)$, aqueous extracts from Ficus capraefolia $(\mathrm{SI}=0.4)$ and water-methanol extracts from Opilia celtidifolia $(\mathrm{SI}=0.4)$.

This shows that the toxicity of a drug depends on effective dose used. Furthermore, it is also important that even though they are effective in treating malaria, the cytotoxicity of to these plants must be taken into account especially by traditional healers for whom the major issue is giving the correct dosage. As shown in previous studies, in traditional medicine practice, medicinal plants can be used but the dosage must be taken into consideration. ${ }^{46,47}$ The results of this study can improve the traditional use of plants and protect people from risks following their administration.

It appears for the first time from scientific investigation that Terminalia avicennoides, Ficus capraefolia and Combretum collinum may be potential sources of antimalarial agents due to their good antimalarial effects and the lack of cytotoxic effects of their extracts. The seven other plants have mostly moderate antimalarial effects but some extracts from Celtis integrifolia, Cordial mixa and Opilia celtidifolia showed cytotoxic effects. These plants can be used in traditional medicine by paying close attention to the dosage. The promising results obtained can be a starting point to seek bioactive compounds by bioguided fractionation and biological studies, for the development of new drugs.

\section{Acknowledgments}

We thank the European Commission, who fully funded the work through project LSHP-CT-2005-018834 of European Commission's 6th Framework Programme (FP6). We thank WHO/TDR, who funded the study site characterisation and the ethnobotanical study to identify traditional healers and medicinal plants through project A30930. We thank all Antimal Consortium members and all staff of CNRFP, where the project was implemented. Special thanks to Professor 
Steven Ward, Susan Jones and Tracy Seddon from LSTM (England), Prof. Henri Vial from University of Montpelier (France), and Prof. Christian Doerig from Monash University (Melbourne, Australia) for their valuable contributions during the project implementation. Thanks to the entire population of the province of Comoe, especially the traditional healers, for their involvement in the plant identification process.

\section{Competing interests}

The authors declare that they have no financial or personal relationship(s) which may have inappropriately influenced them in writing this paper.

\section{Authors' contributions}

S.S. (Centre National de Recherche et de Formation sur le Paludisme) was the project coordinator, the person in charge of overseeing all research activities in the field and the laboratory, the data analysis, the writing of the paper. G.A. (Centre National de Recherche et de Formation sur le Paludisme) contributed to the project implementation by supervising laboratory activities and the paper review. O.L.P. (Centre National de Recherche et de Formation sur le Paludisme) was a student who contributed to the plant harvesting and implementation of laboratory activities. S.S.B., T.A. (Centre National de Recherche et de Formation sur le Paludisme) were in charge of monitoring the research activities, quality control activities, data validation and the paper review. T.D. and N.B. (University of Milan) are responsible for the laboratory in Milan where they trained on pLDH technique and technology transfer the CNRFP staff, and contributed to the monitoring of susceptibility tests, the scientific data validation and the paper review.

\section{References}

1. Wellems TE, Plowe CV. Chloroquine-resistant malaria. J Infect Dis. 2001;184(6): 770-776. http://dx.doi.org/10.1086/322858

2. WHO. World Malaria Report, Geneva; 2010

3. Roselyne NT, Leonardo L, Cinzia CN, Geme UD, Serge RY, Giulio L, et al. Potential o a Khaya ivorensis-Alstonia boonei extract combination as antimalarial prophylactic remedy. J Ethnopharmacol. 2011;137:743-751. http://dx.doi.org/10.1016/j.jep. 2011.06.036

4. DGISS - Mission Ministère de la Santé. Utilisation des données statistiques www. insd.bf/fr/IMG/ARC-SSN_Rapport_final_Sommaire_sante.pdf; 2010.

5. Sirima SB, Gansane A. Artesunate-amodiaquine for the treatment of uncomplicated malaria. Expert Opin Investig Drugs. 2007;16:1079-1085. http://dx.doi.org/10.1517/ 13543784.16.7.1079

6. Sah NK, Alker AP, Sem R, Susanti Al, Muth S, Maguire JD et al. Molecular surveillance for multidrug-resistant Plasmodium falciparum, Cambodia. Emerg Infect Dis. 2008;14(10):1637-1640. http://dx.doi.org/10.3201/eid1410.080080

7. Wongsrichanalai C, Meshnick SR. Declining artesunate-mefloquine efficacy against falciparum malaria on the Cambodia-Thailand border. Emerg Infect Dis. 2008;14(5):716-719. http://dx.doi.org/10.3201/eid1405.071601

8. Alker AP, Lim P, Sem R, Shah NK, Yi P, Bouth DM, Tsuyuoka R et al. Pfmdr1 and in vivo resistance to artesunate-mefloquine in falciparum malaria on the Cambodian-Thai border. Am J Trop Med Hyg. 2007;76(4):641-647.

9. Holmgren G, Hamrin J, Svard J, Martensson A, Gil JP, Bjorkman A. Selection of pfmdr1 mutations after amodiaquine monotherapy and amodiaquine plus artemisinin combination therapy in East Africa. Infect Genet Evol. 2007;7(5):562-569. http:// dx.doi.org/10.1016/j.meegid.2007.03.005

10. WHO. World Malaria Report, Geneva; 2008

11. Gessler MC, Tanner M, Chollet J, Nkunya MHH, Heinrick M, Tanzanian medicina plants used traditionally for the treatment of malaria: in vivo antimalarial and in vitro cytotoxic activities. Phytother Res. 1995;9:504-508. http://dx.doi.org/ 10.1002/ptr.2650090708
12. Muregi FW, Chhabra SC, Njagi EN, Lang'at-Thoruwa CC, Njue WM, Orago et al. In vitro antiplasmodial activity of some plants used in Kisii, Kenya against malaria vitro antiplasmodial activity of some plants used in Kisii, Kenya against malaria and their chloroquine potentiation effects. J Ethnopharm
239. http://dx.doi.org/10.1016/S0378-8741(02)00327-6

13. Iwu MM, Jackson JE, Schuster BG. Medicinal plants in the fight against leishmaniasis. Parasitology Today. 1994;10:227-229. http://dx.doi.org/10.1016/ 0169-4758(94)90398-0

14. Newman DJ, Cragg GM. Natural products as sources of new drugs over the last 25 years. J Nat Prod. 2007;70(3):461-477. http://dx.doi.org/10.1021/np068054v

15. Traoré A, Derme Al, Sanon S, Gansane A, Ouattara Y, Nebié I, Sirima SB. Connaissances ethnobotaniques et pratiques phytothérapeutiques des tradipraticiens de santé de la Comoé pour le traitement du paludisme : processus d'une recherche scientifique de nouveaux antipaludiques au Burkina Faso. Pharmacologia. 2009;43:35-46.

16. Sanon S, Ollivier E, Azas N, Mahiou V, Gasquet M, Ouattara CT, et al. Ethnobotanical survey and in vitro antiplasmodial activity of plants used in traditional medicine in Burkina Faso. J Ethnopharmacol. 2003;86(2-3):143-147. http://dx.doi.org/ 10.1016/S0378-8741(02)00381-1

17. Trager $W$ and Jensen JB. Human malaria parasites in continuous culture. Science. 1976;193(4254):673-675. http://dx.doi.org/10.1126/science.781840

18. Makler MT, Ries JM, Williams JA, Bancroft JE, Piper RC, Gibbins BL, Hinrichs DJ. Parasite lactate dehydrogenase as an assay for Plasmodium falciparum drug sensitivity. Am J Trop Med Hyg. 1993;48:739-741.

19. Deharo E, Bourdy G, Quenevo C, Munoz V, Ruiz G, Sauvain M. A search for natural bioactive compounds in Bolivia through a multidisciplinary approach. Part V. Evaluation of the antimalarial activity of plants used by the Tacana Indians. J Ethnopharmacol. 2001;77:91-98. http://dx.doi.org/10.1016/S03788741(01)00270-7

20. Mosmann T. Rapid colorimetric assay for cellular growth and survival: application to proliferation and cytotoxicity assays. J Immunol Methods. 1983;65(1-2):55-63. http://dx.doi.org/10.1016/0022-1759(83)90303-4

21. Azas N, Laurencin N, Delmas F, Di Giorgio C, Gasquet M, Laget M et al. Synergistic in vitro antimalarial activity of plant extracts used as traditional herbal remedies in Mali. Parasitology Research. 2002;88:165-171. http://dx.doi.org/10.1007/ s004360100454

22. Shuaidu MN, Wuyep PA, Yanagi T, Hirayama K, Tanaka T, Kouno I. The use of microfluorometric method for activity-guided isolation of antiplasmodial compound from plant extracts. Parasitol Res. 2008;102(6):1119-1127. http:// dx.doi.org/10.1007/s00436-008-0879-6

23. Aires A, Fernandes C, Carvalho R, Bennett RN, Saavedra MJ, Rosa EA. Seasonal effects on bioactive compounds and antioxidant capacity of six economically important brassica vegetables. Molecules. 2011;16(8):6816-6832. http://dx.doi. org/10.3390/molecules16086816

24. Karl S, Wong S, St Pierre TG, Davis TM. A comparative study of a flow-cytometrybased assessment of in vitro Plasmodium falciparum drug sensitivity. Malar J. 2009;8:294. http://dx.doi.org/10.1186/1475-2875-8-294

25. Baba-Moussa F, Akpagana K, Bouchet P. Antifungal activities of seven West African Combretaceae used in traditional medicine. J Ethnopharmacol. 1999;66:335338. http://dx.doi.org/10.1016/S0378-8741(98)00184-6

26. Bizimana N, Tietjen U, Zessin KH, Diallo D, Djibril C, Melzig MF, et al. Evaluation of medicinal plants from Mali for their in vitro and in vivo trypanocidal activity. J Ethnopharmacol. 2006;103(3):350-356. http://dx.doi.org/10.1016/j.jep.2005. 08.023

27. Abdullahi AL, Agho MO, Amos S, Gamaniel KS, Wambebe C. Antidiarrhoera activity of aqueous extract of Terminalia avicennoides roots. Phytother Res. 2001;15(5):431-434. http://dx.doi.org/10.1002/ptr.860

28. Asres K, Bucar F, Knauder E, Yardley V, Kendrick H, Croft SL. In vitro antiprotozoal activity of ectract and compounds from the stem bark of Combretum molle. Pytother. Res. 2001;15:613-617. http://dx.doi.org/10.1002/ptr.897

29. Asres K, Mazumder A, Bucar F. Antibacterial and antifungal activities of extracts of combretum molle. Ethiop Med J. 2006;44(3):269-277.

30. Masoko P, Picard J, Eloff JN. The antifungal activity of twenty-four Southern African Combretum species (Combretaceae). S. Afr. J. Bot. 2007;73:173-183. http://dx.doi.org/10.1016/j.sajb.2006.09.010

31. McGaw LJ, Rabe T, Sparg SG, Jager AK, Eloff JN, Staden JV. An investigation on the biological activity of Combretum species. J Ethnopharmacol. 2001;75:45-50. http://dx.doi.org/10.1016/S0378-8741(00)00405-0

32. Odda J, Kristensen S, Kabasa J, Waako P. Larvicidal activity of Combretum collinum Fresen against Aedes aegypti. J. Vector. Borne. Dis. 2008;45:321-324

33. Muregi FW, Chhlabra SC, Njagi EN, Lang'at-Thoruwa CC, Njue WM, Orago AS et al. In vitro antiplasmodial activity of some plants used in Kisii, Kenya against malaria and their chloroquine potentiation effects. J Ethnopharmacol. 2003;84(2-3):235-237.

34. Zhang, HJ, Tamez PA, Aydogmus, Z, Tan GT, Saikawa Y, Hashimoto K, et al. Antimalarial agents from plants. III. Trichothecenes from Ficus fistulosa and
Rhaphidophora decursiva. Planta Medica. 2002;68:1088-1091. http://dx.doi. Rhaphidophora decursiva.
org/10.1055/s-2002-36350

35. Namdaung U, Aroonrerk N, Suksamrarn S, Danwisetkanjana K, Saenboonrueng J, Arjchomphu W, et al. Bioactive constituents of the root bark of Artocarpus rigidus subsp. rigidus. Chemical \& Pharmaceutical Bulletin. 2006;54:1433-1436. http:// subsp. rigidus. Chemical \& Pharma
dx.doi.org/10.1248/cpb.54.1433

36. Sonibare, MA, Soladoye, MO, Ekine-Ogunlana Y. A chemotaxonomic approach to the alkane content of three species of Anthocleista Afzel. (Loganiaceae). African Journal of Biotechnology. 2007;6(13):1516-1520.

37. Madubunyi II, Adam KP, Becker H. Anthocleistol, a new secoiridoid from Anthocleista nobilis. Journal of Biosciences. 1994;49(3-4):271-272. 
38. Almeida J, Bueno C. Immunophenotypic identification, enumeration, and characterization of human peripheral blood dendritic cells and dendritic-cell precursors. Curr Protoc Cytom. 2001;6:6-9.

39. Motamedi H, Darabpour E, Gholipour M, Seyyed Nejad SM. In vitro assay for the anti-brucella activity of medicinal plants against tetracycline-resistant Brucella melitensis. J. Zhejiang. Univ. Sci. B. 2010;11(7):506-511. http://dx.doi. org/10.1631/jzus.B0900365

40. Muthaura CN, Rukunga GM, Chhabra SC, Omar SA, Guantai AN, Gathirwa JW, et al. Antimalarial activity of some plants traditionally used in treatment of malaria al. Antimalarial activity of some plants traditionally used in treatment of malaria in Kwale district of Kenya. J Ethro
org/10.1016/j.jep.2007.04.018

41. Nakano T, Yang TH, Terao S. Studies on the alkaloides of Securinega virosa Pax et Hoff._I. Telmmron. Tetrahedron. 1963;19(4):609-619. http://dx.doi.org/10.1016/ S0040-4020(01)98547-3

42. Gangoué-Piéboji J,Pegnyemb DE,Niyitegeka D, Nsangou A, Eze N, Minyem $C$, et al. The in-vitro antimicrobial activities of some medicinal plants from Cameroon. Ann Trop Med Parasitol. 2006;100(3):237-243. http://dx.doi.org/ 10.1179/136485906X86365
43. Deeni YY, Sadiq NM. Antimicrobial properties and phytochemical constituents of the leaves of African mistletoe (Tapinanthus dodoneifolius (DC) Danser) (Loranthaceae): an ethnomedicinal plant of Hausaland, Northern Nigeria. (02)00244-1
(02). 2002;83(3):235-240. http://dx.doi.org/10.1016/50378-8741

44. Lusakibanza M, Mesia G, Tona G, Karemere S, Lukuka A, Tits M, Angenot L, used in M. In vitro and in vivo antimalarial and cytotoxic activity of five plants http://dx.doi.org/10.1016/j.jep.2010.04.007

45. Ayuko TA, Njau RN, Cornelius W, Leah N, Ndiege IO. In vitro antiplasmodial activity and toxicity assessment of plant extracts used in traditional malaria therapy in the Lake Victoria Region. Mem Inst Oswaldo cruz. 2009;104(5):689-694. http://dx.doi. org/10.1590/S0074-02762009000500004

46. Bisi-Johnson MA, Obi CL, Hattori T, Oshima Y, Li S, Kambizi L, et al. Evaluation of the antibacterial and anticancer activities of some South African medicinal plants. BMC Complement Altern Med. 2011;17:11-14.

47. Ikpeme EV, Ekaluo UB, Kooffreh ME, Udensi O. Phytochemistry and heamatological potential of ethanol seed leaf and pulp extracts of Carica papaya (Linn.). Pak I Bio Sci. 2011;14(6):408-411. http://dx.doi.org/10.3923/pjbs.2011.408.411 